Journal of Social and Development Sciences

Vol. 3, No. 3, pp. 99-107, Mar 2012 (ISSN 2221-1152)

\title{
Migration and Inter-Dependence, Sustainable Urbanism in the Pearl River Delta Region, South China
}

\author{
${ }^{*}$ Alam, A.F.M. Ashraful ${ }^{1}$, Khalil, Momtaj Bintay ${ }^{2}$ \\ ${ }^{1}$ Khulna University, Khulna, Bangladesh \\ ${ }^{2}$ Khulna University of Engineering and Technology, Khulna, Bangladesh \\ *afmalam@gmail.com
}

\begin{abstract}
Under influence of globalization regional boundaries seem to be melted with the hands of migrants and pave the integration process. Ideally integration occur through voluntary linking in the economic and political domains of two or more formerly independent states to the extent that authority over key areas of national policy is shifted towards the supra-national level. The Pearl River Delta (PRD) region of South China is unique as its status transformed from an international boundary between the UK and the People's Republic of China (PRC) to an internal boundary inside China under 'one country-two systems' in 1997. Cross-border migration between Hong Kong and the PRD can be seen as the discourse of dependant development. Contrary to the contribution of migrants through spontaneously locating and relocating themselves across border with their social and entrepreneurial interplay in history, governments responded selectively to cross-border issues While most research emphasize economic and political aspects, analysis into the migration history reveals that integration in the PRD region is a unique form of 'inter-dependent urbanism' through the hands of temporary and permanent migrants who once happened to be separated by force, are merging in the same nation-state recently. This subtly perceived trend of urbanization has scope to achieve sustainability of the region.
\end{abstract}

Keywords: Migration, Inter-dependent urbanism, Regional integration, Sustainability

\section{Introduction}

Globalization has often proved itself a boundary melting process over regions (Yang, 2006). Ideally it seeks integration to maintain voluntary linking in the economic and political domains of two or more formerly independent states to the extent that authority over key areas of national policy is shifted towards the supranational level (Mattli, 1999). The linkages also instigate pattern change in cross border flow of people which ramifies significant impact on the urbanization process of the region. But often contribution of these migratory people remains unnoticed by the mainstream. Nevertheless, the migration favors strong regional economic development through offering technological knowledge, best natural resources of both parts and cultural diversity, thus impeding sustainability of the region. The Pearl River Delta (PRD) region (shown in Figure 1) is unique as its status transformed from an international boundary between the UK and the Peoples Republic of China (PRC) to an internal boundary inside China under 'one country-two systems' in 1997 (Cheung, 2006).Cross-border phenomena between Hong Kong and the PRD can be seen as the discourse of dependant development (Frank, 1978)although primarily economic. At times sustainability was obstructed through differentiation of interests, information gap for environmental management and duplicating efforts (Ling, Hanna, \& Dale, 2009). Contrary to the contribution of migrants through spontaneously locating and relocating themselves across border with their social and entrepreneurial interplay in history, governments responded selectively to cross-border issues (Shen, 2004). While most research emphasize economic and political aspects, this paper reveals that integration in the PRD region is a unique form of 'inter-dependent urbanism' through the hands of temporary and permanent migrants who once happened to be separated by force, have been merging in the same nation-state in recent decade. This research work tries to reinstate that the subtly perceived migration of citizens from both sides has substantial contribution towards all developments and they are the mainstay behind the unique form of interdependent urbanization and has contributed to achieve sustainability of the region. 
Figure 1: Boundary of Hong Kong, PRD and Guangdong; Source: R. C. K Chan, 1998

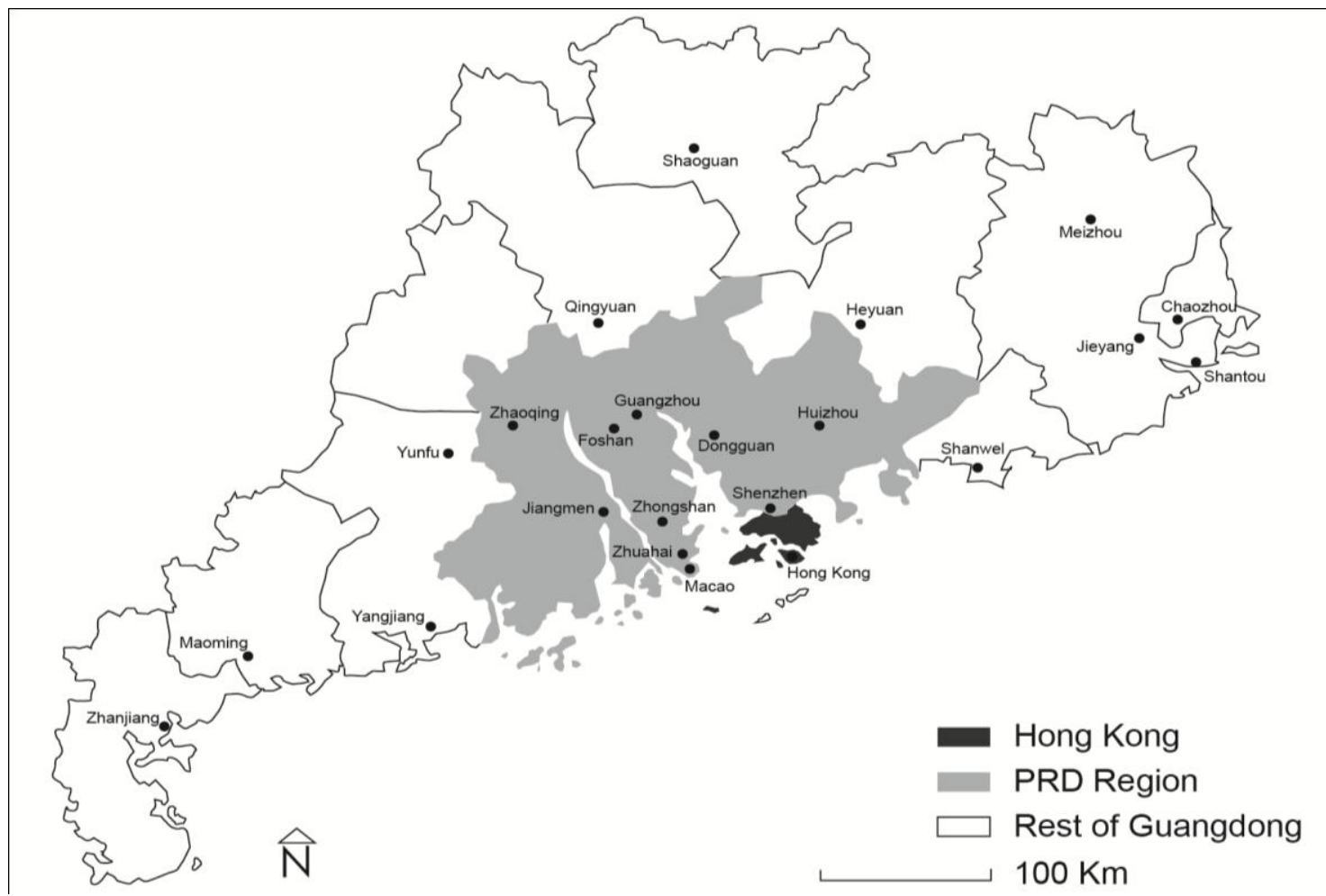

This paper conducts literature review on the migration history of the Pearl River Delta region of South China and tries to understand the nature of integration and its effect on the urbanization processes. Furthermore, with some theoretical insights it suggests that cross border migration has positive effect towards interdependent urbanism of places across border and key to regional sustainability. The migratory phenomena of Hong Kong- PRD context requires special attention because of their two different political systems existing in the post-reunification China - a first social experiment of its kind in the world(Chan \& Cheng, 2002). The outcome of the study will significantly contribute to future cross border policy making, urban governance and land use planning of the region where the city-state of Hong Kong will merge into mainland China after the 50 years 'One Country-two Systems' agreement ends.

\section{Theoretical understandings: Migration, interdependence \& sustainable urbanism}

Historically, urbanization assumed two changes (Anderson, 1964); firstly, transformation of agrarian workforce to industrial one with substantial change in dwelling pattern from rural to urban and secondly, concentration of population (Tisdale, 1942). For a particular region it had been quite difficult to possess an infinite range of options for that concentration to pull migrants incessantly over decades. Migration depends on 'unbalanced distribution' (Skeldon, 1997b) of elements (i.e., human needs) between origin and destination. The range of distribution often determines whether it is a permanent movement or will again occur with the change of needs. Investigation into literature prompt insights into global processes of socio-economic transformation that migrants create, maintain and make use of modes of exchange and relationship between nation-state borders. Of those numerous activities relating to cross-border contacts, coalitions and interactions, not every aspect can be controlled by the organs of government (Nye \& Keohane, 1971). The activities include movements of information, money, objects and people across borders and they coerce the urbanization process. Through these activities, transnational connections can radically transform modes of collective action and interdependence among each other (Rosenau, 1980).

Cross border migration boosts the management frameworks, infrastructure development, human resources, international and local level border concessions and treaty waivers, impeding significant role in the 
sustainable management of trans-frontier urban resources (Timothy, 1999).Consequently, the migrants' lives are also affected through sustained connections with people and institutions in places of origin or elsewhere in Diaspora (family obligations, marriage patterns, remittances, political engagement, religious practice, regular visits, media consumption and so on)(Vertovec, 2003). The more integrated and complementary the two sides in relation to the border, the higher level of dependency is to be transpired through mutually retaining their desired rhythm of population concentration. Here lies the logic of this study. Through investigation into the literature, the paper first explores the complementary nature of the cross border setting and the push-pull factor of migration in the PRD and establishes the dependency matrix mainstay for sustainable urbanism. As destination has to receive migrants from origins, origins also receive goods and service they produce in destination, under such reciprocal relationship, competing urban areas grow and increasingly get interlinked and develop into an instrumentality whose physical area may be defined but the force it exerts to a region cannot be limited to the country or the physical area itself. Owing to the 'interdependent' nature of migration, both the more and less developed places come to be increasingly tied together and get urbanized (Anderson, 1964).

\section{History of Migration and 'Inter-Dependence': Before 1979: Integration Unrealized}

Figure 2 shows that pre-1979 border was loosely permeable until 1949 and after formation of the PRC it became officially impermeable, yet remained semi-permeable for getaway people (Chan, 2006). Guangdong province remained underdeveloped for long due to tight central control and the 'refusal to deal' policy (Lee \& McCobb, 1971) imposed by the US trade embargo. In contrast, Hong Kong underwent massive industrial development through influx of entrepreneurial skills, labor and capital of refugees from the PRC(Szczepanik, 1960). Refugees included a substantial minority of extraordinarily well educated and industrially experienced capitalists from Shanghai (Young, 1992). Owing to the less-absorbent PRD border coupled with Hong Kong products high demand in world market and lack of competitors; Hong Kong quickly established itself as an export-led industrial economy (Koo, 1968) where young migrants from China, legal or otherwise, had been continuous source of labor-supply. In fact, during the great Proletarian Cultural Revolution (1966-1974), thousands of migrants relocated to Hong Kong unchecked, causing 3.5\% increase of territory's population (Chan, 1998).

1979- 1997: Integration Realized: In early 1980's Hong Kong's industries were facing difficulties to increase in number and size due to limited land and escalating labor cost and government's restriction on employing illegal immigrants (Destexhe, 1995)which intensified their global competitiveness (Hsieh \& Woo, 2005). China's open door policy provided timely opportunity to shift their manufacturing base to areas of Guangdong till early 1990s (Young, 1992). This in turn led Hong Kong to invest heavily in infrastructure (e.g. the Guangzhou-Shenzhen highway) to reduce spatial barriers which ultimately consolidated the future urban landscape of the region. As labor and land were unexpectedly cheap (Schiffer, 1983), south China emerged as the fastest growing region of the nation. Hong Kong residents also joined to industries over a prolonged fifteen years period and bonded socially through second marriages in the PRC (So, 2003). Afterwards, their spouses and children had to be siphoned and they caused profound socio-economic impacts in urban Hong Kong (Sung \& Wong, 2000).Unlike western cities outflow of industrial capital to the PRD compelled Hong Kong policy makers to economic restructuring than decline (Lui \& Chiu, 2001). Tertiary innovative sectors replaced old industrial structure to provide sound business environment for foreign investors since mid1980s (Chen, Chang, \& Zhang, 1995). China itself was one of the biggest clients of Hong Kong's world class banking service. Thus Hong Kong strengthened its role as 'front shop' for the 'back factory' of the PRD's lowend economic activity (Sit, 1989, 1998; Yang, 2004). Eventually Hong Kong's 'general labor importation scheme' was substituted by 'special labor importation scheme' in 1990 (Law \& Lee, 2006; Prasai, 1993; Skeldon, 1997a). Complementary competitiveness was realized by both as key factor for future success. In 1992, restriction on foreign investment was relaxed as the PRD embraced global market principles(Lin, 1999)introducing Special Economic Zones (SEZ) to enable producer service (Pannell, 2002). Therefore, the last decade before the 'handover' saw massive economic restructuring in the PRD (Sit, 2001) which eventually repositioned both white blue collared citizens in both sides of the border-line. 
Figure 2: Migration between Hong Kong \& PRD; Source: Author

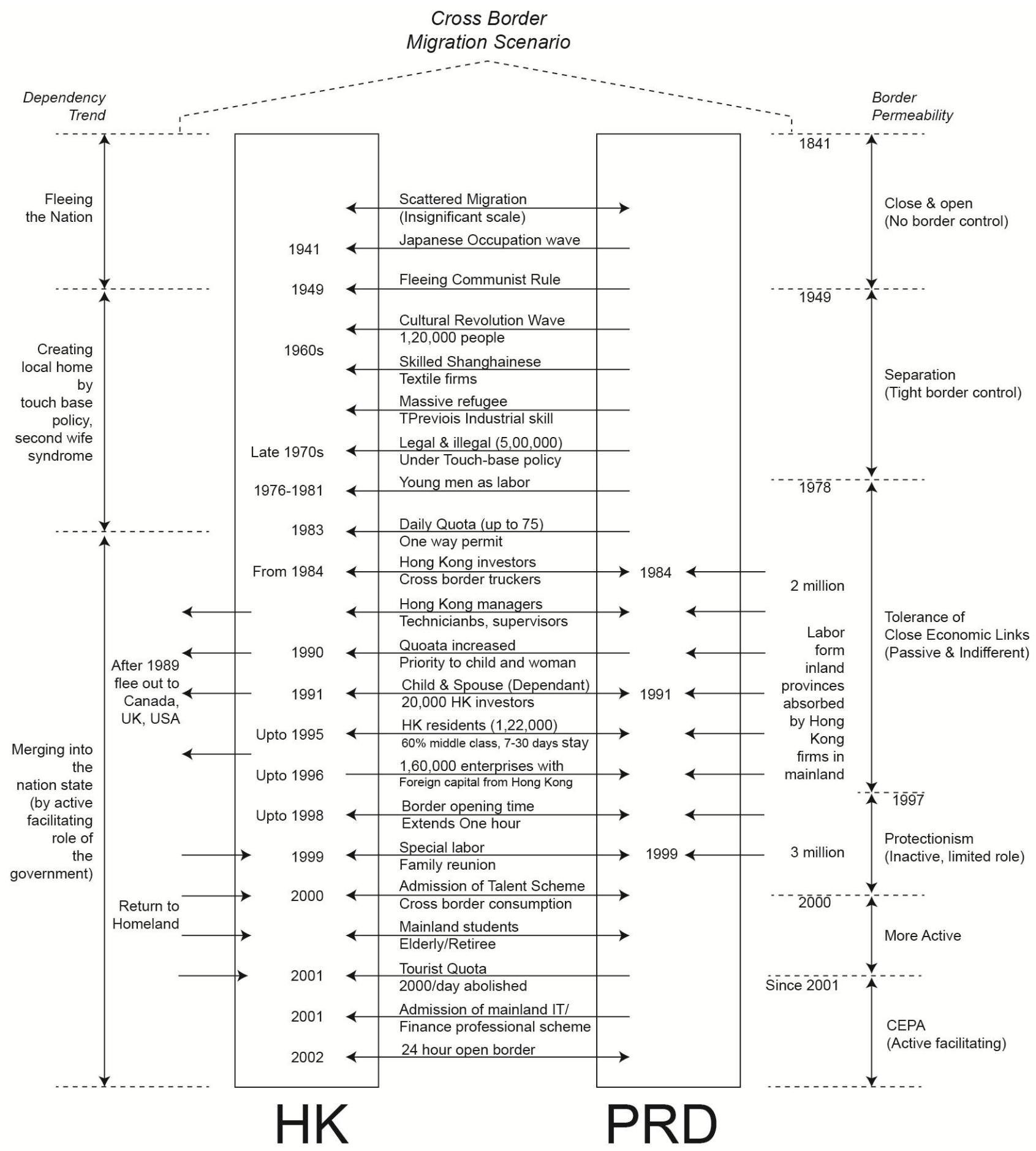

1997 Beyond: Integration Challenged: The 'positive perception' (Wong \& Wan, 2009) of the 'one country, two systems' was instantly challenged by economic stresses (M. C. Wong \& Lam, 2008) which exposed the vulnerability of Hong Kong's tertiary industry(Chan, 1998; Yeh \& Xu, 2006). Central government of the PRC started restructuring the PRD (Garnaut, Song, \& Yao, 2006) from its edge city status of China to the center of south China leaving back its labor intensive industries to less developed areas. In such turmoil there was hardly any labor intensive job left for mainlanders in Hong Kong and policy makers became keen on 
consolidating the already established producer service base and became selective in choosing immigrants from mainland under different talent quota. Large number of Hong Kong professionals also started working in China in due course (Sung, 2004). In fact, more people from Hong Kong started travelling to Shenzhen not only for job but also to meet cheap recreational needs on regular day to day basis(Wang, 2004). Increasingly Hong Kong people tend to reside, take up jobs and acquire permanent dwellings in the mainland (Planning Department, 2009). By 2020, large proportion of Hong Kong population is willing to retire in the vicinity which speculates development of adequate services and civil infrastructure and will further transform the future urban landscape of south China(Kwok, 1986).Similarly, after the abrogation of the 'tourist group quota' by 'individual visit scheme' in 2003, number of mainlanders touring Hong Kong escalated (Choi, Liu, Pang, \& Chow, 2008). The visit scheme substantiated with a speedy and convenient transportation framework also inspired large number mainland Chinese population to come Hong Kong for better education, health care and high end consumer product. Therefore, Hong Kong side of the South China has started investing heavily in different sectors (especially cultural, the West Kowloon Cultural District initiative is a large attempt in this concern) to retain inflow from the region.

Figure 3: Dependency matrix between Hong Kong and the PRD; Source: Author

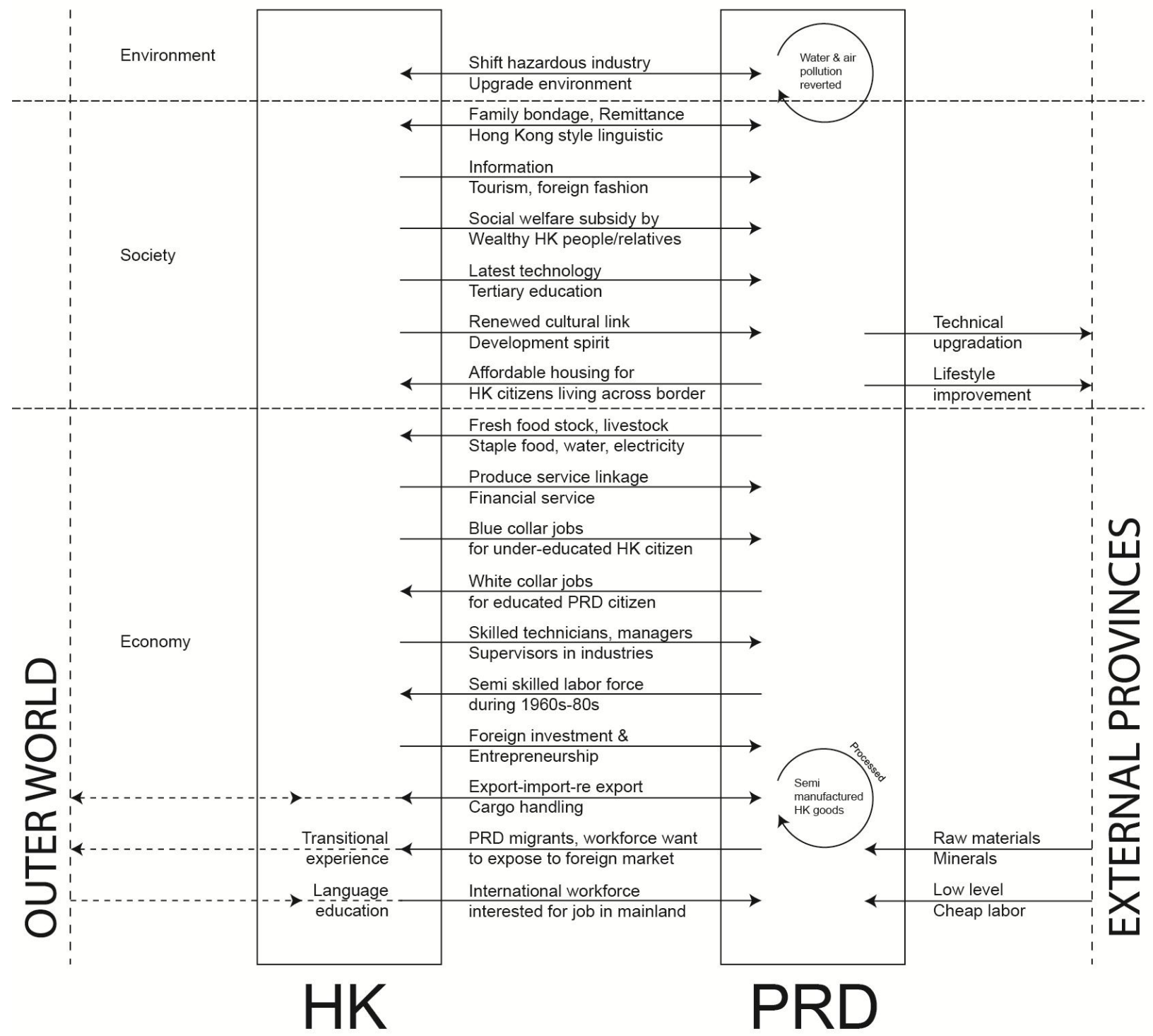




\section{Dependency Matrix \& Sustainable Urbanism in the PRD}

Dependency matrix in the context of the PRD is shown in figure 3. Visible migration instigated in the mainland due to political instability in the 1950s and 1960s. Eventually, large proportion of immigrants entered into Hong Kong aiming at the opportunity of employment and it governed both way migration during 1970 s and 1980s. Family reunion, tourism, education, affordable housing and consumer goods got priority afterwards. Migration of first three decades before nineties was relatively permanent. With the advancement of high-speed transportation and relaxation of border administration; permanent migration decreased substantially. Over the last half century the PRD has been a region with mobile population. There has been either an attraction in Hong Kong or a driving force in the other side to retain mobility. This dynamic inequality of both ends performed the insertion of various phases of urbanization in Hong Kong and south China where migration had been the mainstay within the limit of the places' carrying capacity and urban sustainability largely depends upon how those competing places interact in this regard. Hong Kong and the south China region are not isolated centers. Rather they are part of the large 'urban corridor' (Choe, 1998)of borderless economies (Thant, Tang, \& Kakazu, 1994).Controlled migration in the region can be the key to sustainability. As more population movement of less permanent nature is increasingly evident, the borderless city governance will act as catalyst where limited land resourced Hong Kong-end will infinitely enjoy opportunities of the whole delta region.Hong Kong is not a discrete entity(So, 2003).Features of interdependence in figure 3 proves that any initiative related to social, economics and political development for Hong Kong side needs to be compatible with the development strategy of the whole PRD or contrariwise. Being an economic growth-oriented outward-looking region, it is a natural magnet for people. The sequential alteration between 'unity and disunity' (Kwok, 1991) where Shenzhen was being Hong Kongized, Guangdong was Shenzhenized, and the whole country was Guangdongized (Chan, 1995; Guldin, 1995), perfectly depict the pace and direction of urbanization from the edge to inland. The PRD's Hong Kong-propelled economic take-off had displaced Shanghai's long been unquestioned supremacy (Chan, 1995) as the harbringer of China's future (Kwok, 1986).Hence the process has neither denied the contribution of other part, nor did it describe the supremacy of only one rather evolves as a strong self sustaining identity of a region.

\section{Conclusion \& Future Direction}

As migration was natural in past, in recent years some percentages of Hong Kong population are trying to get back to their roots, some are attempting to have a setback from the high consumption cost of Hong Kong in Shenzhen, but still desire to depend on Hong Kong for children's education, health care, etc(Ambrose \& Chow, 2006). These return migrants (Ma, 2001) will cause significant spatial changes in the PRD's urbanization process in following decades. On the other hand, people from mainland choose Hong Kong as their trustworthy source of world class service, consumer goods and tourism venue (Chan, 2006). In a way it confirms the 'dependant urbanization' phenomenon as well as contributes to social and cultural sustainability. Therefore, citizens of both ends may want to satisfy their best desired options from Hong Kong and the PRD in all possible aspects. High speed cross border rail network will be a catalyst to such choices within the concept of the functional city system (Marcotullio, 2001).This paper well demonstrates the importance of less formal cooperation of the migrant population for laying the groundwork for sustainable management of cross-border urban development. Although migration is natural but they need some pull factors to initiate. Urban policy makers in the greater PRD region should be more proactive not to control the amount of migration; rather should focus on the bilateral treaties, official treaty waivers, offer the array of socio-economic opportunities to catalyze the cross border flow. The issue of cross border migration should not be seen from the perspective of political control over people, rather it should be nurtured as a spontaneous process of inter-state interdependence among citizens, especially under the unique 'one country-two systems' mechanism between the PRC and Hong Kong.

Further research is needed on this issue with more empirical evidences. As the current study primarily examines the secondary literature, more recent cross border activities and their urbanization impact might not been depicted at their desired detail. However, the research substantially clarifies that migration in the PRD although primarily economy-led, but was not divorced from social and environmental. Under postwestern modernity, the region is expected to undergo extreme spatial changes. Cities in the whole Guangdong province will be competing and increasingly the whole region will appear more polycentric and urbanized. 
Importance of Hong Kong as the gateway to the PRC is being intense than ever. Unlike from the past, increasing number of global actors is adding pristine dynamics to the cross-border governance. Therefore, nature of migration and elements of dependency become very complex and near to unpredictable matrix. The paradox of future of the greater PRD will depend on how both government and citizens of both sides complement their respective urban settings by giving themselves space to depend and develop sustainably, failure in doing so could render the region the victim of its own success (Chan, 1998).

\section{Reference}

Ambrose, M. A. \& Chow, N. W. S. (2006). The Residential Mobility and Housing Preferences of Hong Kong Retiree Movers to the Pearl River Delta. In A. G. O. Yeh, V. F. S. Sit, G. Chen \& Y. Zhou (Eds.), Developing a Competitive Pearl River Delta in South China Under One Country-Two Systems (229-252). Hong Kong: Hong Kong University Press.

Anderson, N. (1964). Aspects of urbanism and urbanization. In N. Anderson (Ed.), Urbanism and urbanization (1-6). Leiden: Brill.

Chan, K. \& Cheng, H. (2002). One Country, Two Systems Cultural Values Reflected in Chinese and Hong Kong Television Commercials. International Communication Gazette, 64(4), 385-400.

Chan, K. L. (2006). Population movement statistics in Hong Kong. Retrieved from http://www.iaos2006conf.ca/pdf/Chan.pdf

Chan, M. K. (1995). All in the family: The Hong Kong-Guangdong link in historical perspective. In R. Y. W. Kwok \& A. Y. So (Eds.), The Hong Kong-Guangdong link: partnership in flux (31-63). Hong Kong: Hong Kong University Press.

Chan, R. C. K. (1998). Cross-border regional development in Southern China. GeoJournal, 44(3), 225-237.

Chan, R. C. K. (2006). Regional Integration and Governance in the Pearl River Delta Region from a CrossBorder Perspective. In A. G. O. Yeh, V. F. S. Sit, G. Chen \& Y. Zhou (Eds.), Developing a competitive Pearl River Delta in South China under one country-two systems (481-508). Hong Kong: Hong Kong University Press.

Chen, C., Chang, L. \& Zhang, Y. (1995). The role of foreign direct investment in China's post-1978 economic development. World Development, 23(4), 691-703.

Cheung, P. T. Y. (2006). Cross-boundary Cooperation in South China: Perspectives, Mechanisms and Challenges. In A. G. O. Yeh, V. F. S. Sit, G. Chen \& Y. Zhou (Eds.), Developing a competitive Pearl River Delta in South China under one country-two systems (449-480). Hong Kong: Hong Kong University Press.

Choe, S. C. (1998). Urban corridors in Pacific Asia. In F. C. Lo \& Y. M. Yeung (Eds.), Globalization and the world of large cities (155-173). Tokyo, Japan: The United Nations University Press.

Choi, T. M., Liu, S. C., Pang, K. M. \& Chow, P. S. (2008). Shopping behaviors of individual tourists from the Chinese Mainland to Hong Kong. Tourism Management, 29(4), 811-820.

Destexhe, J. F. (1995). Hong Kong and 1997: The facts. In W. Menski (Ed.), Coping with 1997: the reaction of the Hong Kong people to the transfer of power (17-56). Staffordshire: Trentham Books Ltd.

Frank, A. G. (1978). Dependent accumulation and underdevelopment. London: Macmillan.

Garnaut, R., Song, L. \& Yao, Y. (2006). Impact and Significance of State-Owned Enterprise Restructuring in China. The China Journal, 55, 35-63.

Guldin, G. E. (1995). Toward a greater Guangdong: Hong Kong's sociocultural impact on the Pearl River Delta and beyond. In R. Y. W. Kwok \& A. Y. So (Eds.), The Hong Kong-Guangdong Link: Partnership in Flux (89-118). Hong Kong: Hong Kong University Press.

Hsieh, C. T. \& Woo, K. T. (2005). The impact of outsourcing to China on Hong Kong's labor market. The American Economic Review, 95(5), 1673-1687.

Koo, S. (1968). The Role of Export Expansion in Hong Kong's Economic Growth. Asian Survey, 8(6), 499-515.

Kwok, D. W. Y. (1991). unification and division in the chinese historical experience. Paper presented at the Historical Changes in Hong Kong and South China: Sociocultural Integration Toward 1997.

Kwok, R. Y. W. (1986). Regional Relationship and Interaction Between Hong Kong and China. In L. Y. Choi, K. W. Fong \& K. Y. W. (Eds.), Planning and Development of Coastal Open Cities (Part II: Hong Kong Section) (159-173). Hong Kong: Center of Urban Studies and Regional Planning, University of Hong Kong.

Law, K. \& Lee, K. (2006). Citizenship, economy and social exclusion of mainland Chinese immigrants in Hong Kong. Journal of Contemporary Asia, 36(2), 217-242.

Lee, L. T. \& McCobb, J. B. J. (1971). United States Trade Embargo on China, 1949-1970: Legal Status and Future 
Prospects. Internation Law and Politics, 3(4).

Lin, G. (1999). State policy and spatial restructuring in post-reform China, 1978-95. International Journal of Urban and Regional Research, 23(4), 670-696.

Ling, C., Hanna, K. \& Dale, A. (2009). A Template for Integrated Community Sustainability Planning. Environmental Management, 44(2), 228-242.

Lui, T. L. \& Chiu, S. W. K. (2001). Flexibility under Unorganized Industrialism? The Experience of Industrial Restructuring in Hong Kong. In F. C. Deyo, R. F. Doner \& E. Hershberg (Eds.), Economic governance and the challenge of flexibility in East Asia (55-78). Lanham, Md.: Rowman \& Littlefield Publishers.

Ma, Z. (2001). Urban labour-force experience as a determinant of rural occupation change: evidence from recent urban-rural return migration in China. Environment and Planning A, 33(2), 237-256.

Marcotullio, P. (2001). Globalization and urban sustainability in the Asia Pacific Region. Taipei: Academia Sinica, Program for Southeast Asian Area Studies.

Mattli, W. (1999). The logic of regional integration: Europe and beyond. Cambridge: Cambridge University Press.

Nye, J. S. \& Keohane, R. O. (1971). Transnational Relations and World Politics: An Introduction. In R. 0. Keohane \& J. S. Nye (Eds.), Transnational Relations and World Politics (ix-xxix). Cambridge, MA: Harvard University Press.

Pannell, C. (2002). China's continuing urban transition. Environment and Planning A, 34(9), 1571-1590.

Planning Department. (2009). Survey of Hong Kong People Living in Shenzhen 2008. Hong Kong.

Prasai, S. B. (1993). Intra-Asian Labor Migration: Redefining the Implications. Asian Survey, 33(11), 10551070.

Rosenau, J. N. (1980). The study of global interdependence: essays on the transnationalization of world affairs. London: Frances Pinter.

Schiffer, J. (1983). Urban enterprise zones: a comment on the Hong Kong model. International Journal of Urban and Regional Research, 7(3), 429-438.

Shen, J. (2004). Cross-border urban governance in Hong Kong: the role of state in a globalizing city-region. The Professional Geographer, 56(4), 530-543.

Sit, V. F. S. (1989). Hong Kong's new industrial partnership with the Pearl River Delta. Asian Geographer, $8(1 / 2), 103-115$.

Sit, V. F. S. (1998). Hong Kong's transferred industrialization and industrial geography. Asian Survey, 38(9), 880-904.

Sit, V. F. S. (2001). Economic integration of Guangdong Province and HK: implications for China's opening and its accession to the WTO. Regional Development Studies, 7, 129-142.

Skeldon, R. (1997a). Hong Kong: colonial city to global city to provincial city? Cities, 14(5), 265-271.

Skeldon, R. (1997b). Migration and development: a global perspective. Harlow, Essex: Longman.

So, A. Y. (2003). Cross-border families in Hong Kong The role of social class and politics. Critical Asian Studies, $35(4), 515-534$.

Sung, Y. W. (2004). Hong Kong's Economic Integration with the Pearl River Delta: Quantifying the Benefits and Costs (Final Report). Retrieved from http://www.cpu.gov.hk/english/documents/new/press/200404\%20PRD\%20report.pdf

Sung, Y. W. \& Wong, K. Y. (2000). Growth of Hong Kong before and after its reversion to China: the China factor. Pacific Economic Review, 5(2), 201-228.

Szczepanik, E. F. (1960). The economic growth of Hong Kong. London: Oxford University Press.

Thant, M., Tang, M. \& Kakazu, H. (1994). Growth triangles in Asia: a new approach to regional economic cooperation. Oxford; Tokyo: Published for the Asian Development Bank by Oxford University Press, .

Timothy, D. J. (1999). Cross-border partnership in tourism resource management: International parks along the US-Canada border. Journal of Sustainable Tourism, 7(3-4), 182-205.

Tisdale, H. (1942). The process of urbanization. Social Forces, 20(3), 311-316.

Vertovec, S. (2003). Migration and other modes of transnationalism: towards conceptual cross-fertilization. International Migration Review, 37(3), 641-665.

Wang, D. (2004). Hong Kongers' cross-border consumption and shopping in Shenzhen: patterns and motivations. Journal of Retailing and Consumer Services, 11(3), 149-159.

Wong, M. C. \& Lam, Y. (2008). Macro stress tests and history-based stressed PD: the case of Hong Kong. Journal of Financial Regulation and Compliance, 16(3), 251-260.

Wong, T. K. \& Wan, S. P. S. (2009). Hong Kong citizens' evaluations of the "one country, two systems" practice. 
In H. H. M. Hsiao \& C. Y. Lin (Eds.), Rise of China: Beijing's Strategies and Implications for the AsiaPacific (270-283). Abingdon: Routledge.

Yang, C. (2004). From Market-Led to Institution-Based Economic Integration: The Case of the Pearl River Delta and Hong Kong. Issues \& Studies, 40(2), 79-118.

Yang, C. (2006). The Pearl River Delta and Hong Kong: an evolving cross-boundary region under one country, two systems. Habitat International, 30(1), 61-86.

Yeh, A. G. O., \& Xu, J. (2006). Turning of the Dragon Head: Changing Role of Hong Kong in the Regional Development of the Pearl River Delta. In A. G. O. Yeh, V. F. S. Sit, G. Chen \& Y. Zhou (Eds.), Developing a Competitive Pearl River Delta in South China Under One Country-Two Systems (63-96). Hong Kong: Hong Kong University Press.

Young, A. (1992). A Tale of Two Cities: Factor Accumulation and Technical change in Hong Kong and Singapore. In O. J. Blanchard \& S. Fischer (Eds.), NBER Macroeconomics Annual (13-54). London and Cambridge: MIT Press. 